\title{
Recantations and the Ars Moriendi in Reformation England
}

\section{Angela Ranson, Dalhousie University}

Voices in his head told Francis Spira that he was damned for all eternity, and the devil tormented him by appearing in his room in the form of a fly. Approximately thirty-five people came to his house in Italy and told him that he was not damned, but despair and desperation had set in after he recanted his Protestant beliefs, and he could not believe them. He was convinced that he had committed the unforgivable sin, so he starved himself and died after eight weeks of suffering. ${ }^{1}$ Immediately, Protestants of Italy and England took up his story and used it as a cautionary tale to fortify people who might consider recanting their beliefs. The story grew in popularity and effectiveness for three centuries. As M.A. Overell said, 'To tell the Spira story became a way of making Protestants be brave, minorities face persecution, converts be committed, atheists be Christian, and the immoral be good.'2

In 1562, fourteen years after Spira's death, Dr. Edward Crome died at home in England. Unlike Spira, he was an old man at death. Spira was a lawyer; Crome preached in English pulpits for over forty years, through the reigns of Henry VIII, Edward VI, and Mary I. Spira died in torment and terror, convinced he was

1Michael MacDonald, 'The Fearful Estate of Francis Spira: Narrative, Identity, and Emotion in Early Modern England'. The Journal of British Studies, Vol. 31, No. 1 (Jan., 1992), 32.

2 M.A. Overell, 'The Exploitation of Francesco Spiera'. The Sixteenth Century Journal, Vol. 26,No. 3 (Autumn, 1995), 634. 
visited by demons; Crome died peacefully. His final words and the scene at his deathbed are not recorded, but according to the man who later collected and translated his works, Miles Coverdale, he died 'making a godly end and a constant confession of the truth'. ${ }^{3}$ Like Spira, Crome believed in justification by faith and did not agree with the doctrine of purgatory. Like Spira, he had been charged with heresy and convicted. Like Spira, he had recanted, at least three times. However, after each of Crome's recantations, his reputation as a godly and steadfast Christian increased. Spira died convinced he was condemned and rejected by God.

Both the contrasts and the similarities between the deaths of Spira and Crome beg the question: why would one man die convinced of his condemnation and the other of his salvation, when both were convicted heretics and both had recanted? The answer lies within the medieval tradition of the ars moriendi. Ars moriendi enabled people of the sixteenth century to die the good death, and so eased the transition from earthly to heavenly life. It provided a pattern for how people prepared for death and a structure for the hour of death itself, when the soul was most vulnerable to the temptations of Satan. It required obedience, faith, and a willing acceptance of the mercy of God, expressed through patience during suffering, peaceful acceptance of God's will, and an attitude of loving forgiveness. In sixteenth-century England, many people aimed to achieve the good death, and believed that barriers to success arose due to their actions on

3Susan Wabuda, "Crome, Edward (d. 1562)," in Oxford Dictionary of National Biography, ed. H. C. G. Matthew and Brian Harrison (Oxford: OUP, 2004); online ed., ed. Lawrence Goldman, January 2008, http://www.oxforddnb.com/ view/article/6749 (accessed December 15, 2009). 
earth. This paper will focus on the barriers that arose due to convictions for heresy, for convicted heretics had to deal with the requirements for a good death very soon after their conviction. They had two options: to recant, as Spira and Crome did, or to die as martyrs. Typically, the achievement of a good death has been associated with martyrdom, for martyrs exemplified the attitudes and actions of the good death. This paper will argue that people who recanted their beliefs could also die a good death, and could use recantation as a means of doing so. It will examine the justifications for recantation, and the varying interpretations of doctrine and authority that allowed them.

First, both heresy and recantation must be defined. Heresy was a defiant adherence to beliefs that differed from standard religious doctrine. It was a both a serious crime and a serious sin in early modern England, but it was considered more amenable to correction than other major sins. Heretics were given the opportunity to recant and return to the church, making recantation one of the main tools used to counter heresy. ${ }^{4}$ The medieval church considered it a form of penance, and in early modern England it maintained this role. It involved revoking religious ideas once held, by making a public confession that could include published statements, acts of penance, or acts of public shame. Recantation could be partial or complete, and it could be expanded or withdrawn. Changing, revoking, or denouncing a recantation was nearly as common as recanting itself, and frequently frustrating for both the audience and the authorities. Edward Crome's third recantation in 1546 took the form of a very convoluted and contradictory sermon. One

4 Brad S. Gregory, Salvation at Stake (Cambridge: Harvard University Press, 1999), 77.

\section{Past Imperfect}

16 (2010) | ( ) | ISSN 1711-053X | elSSN 1718-4487 
witness to the event called it 'canting, recanting, decanting, or really double canting'. ${ }^{5}$

Since church and state were woven firmly together in sixteenth century England, heresy as a sin and a crime was frequently connected with treason. However, in contrast with treason trials, which a commission of oyer and terminer conducted in a secular court, the local bishop's consistory court conducted heresy trials. The system of the trial offered frequent opportunities to recant: first, before the sheriff at the time of arrest, and then after the first night in prison. Priests offered it during the imprisonment and interrogation stage. The bishop offered it during the trial, and repeated the offer both before and during the sentence of condemnation. If condemned heretics accepted none of these opportunities, the sheriff offered the recantation option once again when he arrived at their cells on the execution day. Finally, the officiating priest at the execution site offered it immediately before the execution began. ${ }^{6}$

Between 1509 and 1603, about six hundred people in England did not accept the offer to recant, and died for their faith. ${ }^{7}$ Some died under charges of treason instead of heresy, but their deaths collectively contributed to the idealization of martyrdom, a tradition supported by the medieval veneration of martyred saints through such books as The Golden Legend. It described the heroic actions and steadfast faith of the martyrs, established standards of behavior for suffering Christians of the sixteenth century and began to associate the ars moriendi with

5 Wabuda, 'Subtle Shadows', 237.

${ }^{6}$ Sarah Covington, The Trail of Martyrdom: Persecution and Resistance in $16^{\text {th }}$

Century England (Notre Dame: Notre Dame Press, 2003), 150, 165.

7 Gabriel Glickman, 'Early Modern England: Persecution, Martyrdom...and

Toleration?', The Historical Journal, 51, 1 (2008), 251.

Past Imperfect

16 (2010) | @ | ISSN 1711-053X | elSSN 1718-4487 
martyrdom. ${ }^{8}$ Dying as a martyr showed a loving response to the loving sacrifice of Christ on the cross. If God could suffer and die for his people, it was not too much to ask for his people to suffer and die for him. ${ }^{9}$ The reward for doing so was to go straight to heaven, there to live with Christ in peace and joy for eternity. As Thomas More said in his Dialogue of Comfort, 'he which suffers...martyrdom for the faith shall have high rewards'.10 One of John Calvin's sermons, published in 1581, said that God considered the martyrs precious that he rewarded them after death, and that it was an honor above the angels to die in defense of God's truth. ${ }^{11}$ Martyrs died very painful deaths, and yet consistently achieved the good death through their perfect faith and obedience, patience in suffering, joy in the midst of pain, and cheerful resignation to their fates.

To some people, it was not possible to achieve the good death without living up to this standard. Those who recanted or conformed were frequently accused of Nicodemism. They were faced with the possibility of a bad death because they had not developed enough patience to endure persecution. ${ }^{12}$ Dying people had to be strong to withstand the battle at the hour of death, when angels and demons fought for control of their souls. They had to have assurance in their faith in order for the angels to win. ${ }^{13}$ As Eamon Duffy has described them, Nicodemites were

\footnotetext{
8 Gregory, 124.

${ }_{9}^{9}$ Gregory, 61.

${ }^{10}$ Sir Thomas More, Utopia with The Dialogue of Comfort ( London: J.M. Dent and Sons, 1933), 153.

11 John Calvin, A sermon of the famous and Godly learned man, master John Calvin (London, 1581), 6 -7.

12 Wabuda, 'Subtle Shadows', 224.

${ }^{13}$ Sister Mary Catherine 0'Conner, The Art of Dying Well: The Development of Ars Moriendi (New York: Columbia University Press, 1942), 5.

Past Imperfect

16 (2010) | @ | ISSN 1711-053X | eISSN 1718-4487
} 
'the timid and half-hearted'. ${ }^{14}$ They were at risk, and the sheer number of them prompted many anti-Nicodemite sermons, tracts, and treatises.

Anti-Nicodemites claimed that Nicodemites were also weakened at the hour of death as they suffered great torments of conscience. Calvin described a guilty conscience as a restless, stormy sea under constant agitation, ${ }^{15}$ and John Hooper threatened that the pain of a guilty conscience could make the pain of suffering and dying seem like nothing. Horror stories of people suffering nightmares, sleepless nights, hallucinations, and satanic visions were common. ${ }^{16}$ The conscience was considered a God-given method of distinguishing right from wrong, or as theorist William Perkins put it in 1606, the conscience was 'placed in the middle between man and God...to be a witness and informer of mankind'. ${ }^{17}$ The bad conscience was responsible for admonishing the faint-hearted, ${ }^{18}$ and assisted in keeping people honest. In 1586, Justius Lipsius wrote A Discourse of Constancy that declared that God's judgments were threefold: eternal, posthumous and internal. Internal judgments all involved the conscience, which tormented people with anxiety, penitence, guilt and fears about salvation, and they were the worst form of judgment because it was impossible to avoid or subdue a troubled mind. ${ }^{19}$

14 Eamon Duffy, Fires of Faith: Catholic England Under Mary Tudor (New Haven: Yale University Press, 2009), 163.

15 William J. Bouwsma, John Calvin: A 16 th Century Portrait (New York: Oxford University Press, 1988), 41.

${ }^{16}$ Jonathan Wright, 'The World's Worst Worm: Conscience and Conformity During the English Reformation', The Sixteenth Century Journal, vol 30, no 1 (Spring 1999), 124.

17 Wright, 114.

${ }^{18}$ Covington, 144.

19 Wright, 118, 125.

Past Imperfect

16 (2010) | @ | ISSN 1711-053X | elSSN 1718-4487 
Conscience was an effective weapon for the antiNicodemites partly because of Francis Spira. He became one of the most well-known, and most frightening, examples of the bad conscience. He suffered in his mind; he felt that judgment had fallen on him threefold; he died the bad death that included all the hallucinations, nightmares, sleepless nights, and satanic visions predicted by anti-Nicodemites. It could be assumed, from the story, that the great battle for the soul that occurred at the moment of death had been a victory for Satan. John Calvin said that he was condemned from the beginning. ${ }^{20} \mathrm{He}$ had committed the unforgivable sin.

With this martyr-inspired ideal for the ars moriendi in place, the flood of anti-Nicodemist literature upholding it, the weapon of the conscience, and the story of Francis Spira serving as a warning for anyone who might ignore it, it seemed next to impossible that anyone who recanted could achieve the good death. Fortunately, not everyone interpreted the ars moriendi so strictly as the anti-Nicodemites. In 1552, Hugh Latimer preached about Francis Spira and denied the idea that there was such a thing as an unforgivable sin. He could not deny that Spira had died sinning against the Holy Ghost in the worst of all sins, but he believed that even that sin could be forgiven. 'The mercy of God', as he said, 'far exceedeth all our sins.'21 This interpretation follows the intent of the ars moriendi more closely, and explains how Crome and others like him could recant and not consider themselves condemned.

The book, A little treatise called ars moriendi was published in 1497, and it guided the priest or layman attending a

20 Overell, 631

21 MacDonald, 46. 
dying person through speeches of admonition and encouragement. It ended with the prayer of the dying, which dying people themselves were prompted to say as the final step in the ritual of private death. It also transcended the private deathbed. When the death was public, so was the ritual, and the gallows speech frequently substituted for the prayer of the dying. Regardless of the charge or the form of execution, the vast majority of people executed in early-modern England followed the same formula. Their speeches began with a humble acknowledgement of sin, then pleaded for mercy from God and the monarch and offered forgiveness to everyone. They then asked for forgiveness in return, gave themselves up to the mercy of God, expressed trust in his grace, and submitted willingly to their execution. ${ }^{22}$

In the speech, the dying accepted their sin; in the prayer they confessed that they had a frail nature. In both speech and prayer the dying asked for mercy, and the prayer specified that God was needed to make the spirit right. In both speech and prayer the dying gave themselves up to the mercy of God, but the prayer allowed for fear and wailing while the speech dismissed any feelings of fear. In both speech and prayer, the dying submitted willingly and trusted in God's grace after death. In the prayer, the dying also asked for a free and sure passage to heaven. This became all the more important once the majority of Protestants rejected the doctrine of purgatory. Without that doctrine guiding what happened after death, the request for a free and sure passage could be interpreted through the tradition of martyrdom to mean that martyrs went straight to heaven to

22 J.A. Sharpe, 'Last Dying Speeches: Religion, Ideology, and Public Execution in Seventeenth Century England', Past and Present, 107 (May 1985), 150-152.

Past Imperfect 16 (2010) | @ | ISSN 1711-053X | elSSN 1718-4487 
be with God. It could also be interpreted to mean that the path to salvation led straight to heaven for everyone. As the prayer said, it was an offer for anyone willing to be saved, and frailty of nature and substance did not preclude salvation.

Another book that helped people learn the ars moriendi, The Doctrinal of Death, also claimed that anyone who asked for the mercy of God at the hour of death could receive it. 'One of the greatest sins is to believe that God is not merciful, for... as long as your soul is in your body you shall have mercy if you ask [for] it.'23 This makes Francis Spira's conviction that his recantation had condemned him look more like an invention of his mind than a legitimate theological position. For heretics, criminals, and those who prayed the prayer as they died of natural causes, the keys to a good death were always obedience, faith, and a willingness to trust God to work out their salvation.

Those keys could be achieved in more ways than the antiNicodemites allowed, and could include recantation or other means of avoiding martyrdom. Even the weapon of the guilty conscience could be countered. To ask someone to consider their conscience was a ubiquitous appeal in early modern England, but the rigidity of the concept was changing, and that made a great difference in the interpretation of how to achieve the good death. In 1555, martyr John Philpot wrote the following letter, which reflected the traditional belief in the danger of working against the conscience. In the process, he also demonstrated its changing role.

Many affirm their conscience will bear them well enough to do all that they do...[their] conscience is

\footnotetext{
23 Anonymous, The Doctrinal of Death (London, 1497), 10.
} 
very large to satisfy man more than God. And although their conscience can bear them so to do, yet I am sure that a good conscience will not permit them so to do: which cannot be good unless it be directed after the knowledge of God's word: and therefore in Latin this feeling of mind is called Conscientia, which soundeth by interpretation, as much as with knowledge. And therefore if our conscience be led of herself, and not after true knowledge, yet we are not so to be excused, as Saint Paul bears witness, saying: although my conscience accuseth me not, yet in this I am not justified. And he [develops] a good conscience with these three sisters, charity, a pure heart, and unfeigned faith. ${ }^{24}$

The catholic faith traditionally defined the 'conscientia' to which Philpot referred as the part of the conscience that applied the premises and precepts of moral behavior stored in the part of the conscience called the 'synderesis'. Traditional catholic belief held that the synderesis was basically good. The interpretation of its knowledge by the conscientia was flawless. Emerging protestant beliefs of the 1500 s decided that both parts of the conscience could be 'impaired by passion, laziness, and other corruptions', ${ }^{25}$ which brought more humanity into that Godgiven method of discernment. Philpot himself implies this, by saying that large consciences satisfy men more than God, and that the conscience can be led of herself.

${ }^{24}$ John Foxe, Acts and Monuments [...] (1570 edition), [online]. (hriOnline, Sheffield). Available from: http://www.hrionline.shef.ac.uk/foxe/. [Accessed: 02.12.2009], 2004.

25 Wright, 119.

Past Imperfect

16 (2010) | @ | ISSN 1711-053X | elSSN 1718-4487 
Other writers examined the limitations and failings of the conscience in more detail. Edmund Bonde published a book titled $A$ devout epistle of treaty for them that have been timorous and fearful in conscience, approximately twenty years before Philpot's letter. He distinguished a healthy fear of God from a servile fear that assumed damnation for every action, and questioned how a legitimately good conscience could make a major $\sin$ out of every sin. He also noted that this sort of conscience could cause unnecessary doubt and waverings in faith, ${ }^{26}$ and condemned the melancholy application of conscience that focused on damnation and despair, which he called scrupulosity. He disapproved of scrupulosity because it was not an act of reason, but the product of an overactive imagination that needed only logical deliberation to prove it false. ${ }^{27}$ This suggests that the conscience, despite its power, was susceptible to reason. As Philpot said, it could be controlled and informed through true knowledge. Spira's guilt could have been assuaged through the assistance of any of those thirty-five people who had come to help him. He could also have assuaged his own guilt, for this limitation of conscience also allowed people to apply personal reason to their consciences.

People in the early modern era were aware that the conscience often failed as a universal standard-bearer of right and wrong, and that it could be used as a catch-all excuse. ${ }^{28}$ Theories like Bonde's widened the basis of interpretation in the matter of conscience, and allowed differing beliefs to fall within

\footnotetext{
26 William Bonde, A devout epistle of treaty for them that have been fearful and timorous in conscience (London, 1534), 3, 4.

27 Bonde, 5.

28 Wright, 131. 
the standards of Philpot's three sisters, provided that they considered the supremacy of God's word. Thus, the good death could be achieved without martyrdom, and alternatives to martyrdom could be employed without sacrificing the conscience. This included the option of fleeing into exile. Sir Thomas More noted in his Dialogue of Comfort that it was perfectly acceptable for accused heretics to 'run away from persecution until such time as it seemed evident that God wished [them] to die a martyr's death'.29 In 1600, George Abbott preached a sermon that said that, 'God would have us to lay down our lives, if needs be for his sake...but we must not leap out [on] our own. Nay we should be so careful, that we should not rashly hazard them, or bring them into peril.' ${ }^{30}$ Accused heretics themselves could determine when it was time to flee, and when God expected a martyr's death.

Robert Barnes, a martyr who had once run away and recanted, specified in his last speech that 'I will not be disobedient in anything, but will obey'.31 This key to the good death was part of the sixteenth-century belief that linked the salvation of subjects under the monarchy to the extent of their obedience to the monarchy. God himself sanctioned and ordained royal power, and as Lacey Baldwin Smith put it, 'every disobedient heart [was assured] a warm welcome in hell'. ${ }^{32}$ In 1554 John Christoferson wrote a treatise that declared that even the evil nature of the king did not excuse a lack of obedience in

\footnotetext{
29 Paul D. Green, 'Suicide, Martyrdom, and Thomas More', Studies on the Renaissance, vol. 19 (1972), 152.

30 George Abbott, An exposition upon the prophet Jonah (London, 1600), 132.

31 Foxe, 1563, 616.

32 Lacey Baldwin Smith, 'Henry VIII and the Protestant Triumph', The American Historical Review, vol. 71, no 4 (July 1966), 125.

Past Imperfect

16 (2010) | @ | ISSN 1711-053X | elSSN 1718-4487
} 
his subjects. Robert Southwell went further still, saying in his Epistle of Comfort that anyone who stood against the crown could not be a martyr. 'They can make no abode with God, that refuse to be peaceable in his church...It shall be no crown of their faith but a punishment of their perfidiousness, it shall not be a glorious end of their religious virtue, but a death of desperation' ${ }^{33}$

This complicated matters of faith for accused heretics. Fortunately, like the conscience, obedience was open to interpretation. As Sarah Covington noted in The Trail of Martyrdom, 'obedience carried different connotations and levels of commitment throughout the century'.34 There were also degrees of obedience, according to A little treatise called ars moriendi. Ungrudging obedience to the sovereign was the first degree, but taking that obedience to the point of death was the seventh degree. Between those two lay a range of behavior that included delayed obedience, half-hearted obedience, and compelled obedience. ${ }^{35}$ Some Reformation leaders also advocated obedience through disobedience. If the choice was to obey God or obey the king, the right choice was to obey God, and suffer the consequences of disobedience to the king. Bishop Hugh Latimer preached that a Christian could disobey the king if he commanded something against God's law, but since rebellion was never acceptable, the disobedient Christian then had to submit to whatever punishment the king meted out, under whatever charge. 36

\footnotetext{
33 King, 306.

34 Covington, 104.

35 Anonymous, Ars Moriendi, 9.

36 Loades, John Foxe, 66, 91.
}

Past Imperfect 16 (2010) | @ | ISSN 1711-053X | elSSN 1718-4487 
If the charge was heresy, a common punishment in early modern England was still penance in the form of recantation. This interpretation of the duty of obedience to both God and King could partly explain why so many people recanted immediately upon arrest for heresy when it involved royal authority. The wording of the recantation would affect this interpretation, as would the instructions given by confessional leaders, but, as Sarah Covington noted, definite divisions between confessions did not solidify until later in the Reformation, making the definitions of their beliefs more liquid. ${ }^{37}$ The authorities questioning accused heretics, and the accused heretics themselves could often phrase their recantations in ways that did not cause pangs of conscience or deny the duty of obedience.

It is important to note here that to deny God was still considered a sin. Heretics who abandoned their beliefs and accepted the opposite point of view were not generally looked on with approval. John Bale called recantation an open shame and said that those who recanted were 'blasphemed, disdained, and abhorred'. ${ }^{38}$ However, just as there were degrees of obedience, there were degrees of recantation. The main weapons at the heretic's disposal were equivocation and mental reservation, and many of the heroes of the early modern era supported their use. In the 1581 sermon, John Calvin said, 'Hereby I do not bind all men of necessity to make a full and entire confession of all they believe...St Paul in this point has used a good moderation, who was as ready as any other freely to maintain the cause of the gospel, as he ought.'39 Robert Barnes, Thomas Garrett, and

\footnotetext{
37 Covington, 29.

${ }^{38}$ John Bale, Yet a Course At the Romish Fox (London, 1543), 21.

39 Calvin, 16. 
William Jerome preached their recantations in public, but a witness noticed that they did so 'gaily, and managed in the same sermon to utter the truth.'40 Some people answered every question during their trials by reciting the Creed, and others added qualifying statements. John Houghton added the phrase 'as far as it is lawful' when he took the Oath of Succession in 1534, and when an Elizabethan woman was about to be interrogated about whether or not she had seen a Catholic priest, Robert Southwell told her it was acceptable to say no as long as she mentally added the phrase, 'not in order to betray him'.41

Playing with the definition of the Catholic Church gave many opportunities for guiltless recantation. At Thomas Bilney's trial in 1527, Wolsey asked him if he thought the Catholic Church could err, a question designed to draw out heretical views about papal supremacy. Bilney talked around the question for a few minutes, and then said that it could not, by mentally defining the Catholic Church as 'the company of the elect, known only to God.' 42 At a mass trial of gospellers in 1556, the bishop phrased the recantation by requiring them to assert that they believed in the Catholic Church and would obey spiritual and temporal authority. What 'catholic' meant was not defined, so the gospellers could accept that recantation. ${ }^{43}$ Also during Mary's reign, Archdeacon William Chelsey took pity on Elizabeth Folkes due to her youth and framed her recantation by making her

40 Wabuda, 233.

41 Covington, 145-147.

42 John F. Davis, 'The Trials of Thomas Bylney and the English Reformation', The Historical Journal, 24, no 4 (December, 1981), 778.

43 Duffy, 140.

Past Imperfect

16 (2010) | @ | ISSN 1711-053X | elSSN 1718-4487 
answer one question: 'Do you believe that there is a catholic church?' She said yes, and he released her. ${ }^{44}$

Dr. Edward Crome employed equivocation and mental reservation with great skill. In 1531, he was arrested for heresy because he had preached against purgatory, pilgrimages, and images. He was told to recant, and agreed to do so in March of 1531. Representatives of Henry VIII gave him fourteen articles to read aloud during his sermon, which he obediently did. However, he discussed each one as he went, and presented opposite points of view that could disprove it. His audience understood his true message, but Crome was not re-arrested, and soon after received the rectorship of St. Mary Aldermary church. In 1541, Crome was arrested again, and the king gave him another recantation and told him to preach it with his sermon. The next Sunday Crome preached his sermon, which presented his views as he always had, and then said 'Some of you have heard that I have recanted and abjured; I assure you, I have not abjured yet'. Then he read the document the king had given him, offered a prayer, and ended the service. The next day, the king called him before him and demanded to know why he had not recanted as he had sworn to do. He acted greatly surprised by the accusation. He had read the document, as requested. He had preached, as requested. He expected the king to be commending him, not accusing him. Royal representatives who had attended the service accused him of saying he had not recanted; he equivocated by claiming that he said that because he had not read the document yet.

${ }^{44}$ Duffy, 165.

Past Imperfect

16 (2010) | @ | ISSN 1711-053X | elSSN 1718-4487 
In 1546, Crome preached a controversial sermon and was arrested for heresy again under the Act of Six Articles. On June 27, he was forced to read aloud a clear recantation, which admitted at the end that he had equivocated and made mental reservations. ${ }^{45}$ This is where Edward Crome's skill is thrown into sharp relief. Although he had thrown himself on the king's mercy, some considered him to be still standing steadfast, since he managed not to specify whether he had equivocated and made mental reservations during his last sermon or during the recantation itself. Others thought he had given up his beliefs, including John Bale, who scornfully compared his 'fall from grace' with Anne Askew's fortitude. ${ }^{46}$ Crome himself hid behind the speculation and continued to work and preach through the rest of Henry's reign and throughout Edward's reign. He was rearrested in 1553 for preaching without a license, and went to prison. 47

It is significant to note that both Spira and Crome obeyed. The Inquisition told Spira to recant in Venice and then again in his hometown, and pay for a tabernacle in his home church. He promised to obey, and did exactly as he was told. 48 Crome appeared before Henry VIII on at least three occasions. Each time he promised to obey, and managed to interpret that obedience in a different way. Crome justified his recantation; Spira did not. Crome died after living a life of faith, trusting in the mercy of God; Spira died in fear, having lost his faith. This shows that the

45 Wabuda, 230-235.

46 Ibid, 236

47 Ibid, 238.

48 Overell, 625 . 
requirement of obedience in the ars moriendi could be interpreted differently, and recantation justified.

I will discuss the second and third parts of the good death together, for faith and the willingness to surrender to God's mercy were closely connected. They involve trusting that imprisonment, shame, and feelings of unworthiness could all be part of preparing for the good death, and yet did not necessarily involve answering the call to martyrdom. In all of this, recantation could be justified on many levels, and most involved dealing with some kind of fear. For men and women accused of heresy, fear played a large part in their decision to recant or choose martyrdom. This is not surprising; even the prayer of the dying acknowledged that death involved 'fear and wailing'. ${ }^{49}$ The conditions in which accused heretics were forced to live also encouraged fear. Early modern prisons were not regulated by the state, and conditions ranged from bad to worse both within prisons and between prisons. Fear also went far beyond the physical. In a letter to his daughter, Sir Thomas More noted that eternal damnation was the only thing he himself feared more than physical pain. ${ }^{50}$ Edmonde Bonde noted that the greatest fear a Christian ought to have is to be separate from God's grace. ${ }^{51}$ While in prison awaiting execution, Robert Glover wrote a letter to his wife encouraging her to keep believing, because 'it was a fearful thing to fall into God's hands' by losing passion for the faith and being seduced away from true teaching. ${ }^{52}$

\footnotetext{
49 Anonymous, Ars Moriendi, 4.

50 Green, 150, 153.

51 Bonde, 3.

52 Foxe, 1570, 1887.
} 
Ars moriendi required that people allow suffering to develop patience and deepen their faith. It required trust in God's mercy, and in his saving grace. Dealing with the fear that came with suffering was part of this ritual, but it did not necessarily lead immediately to death. First, they had to be resolved and certain that death was the choice to make. Hazarding life was not natural and God would not approve it unless the cause was sure. If it was not, as Paul promised in 1 Corinthians 10:13, God was faithful. He would not allow his people to be tempted beyond what they could bear. As John Scory said in a 1555 sermon, anyone who called on God would be delivered, because God was merciful and promised to help people when they were in trouble. ${ }^{53}$

Falling into temptation took many forms; corruption from the faith was one of the most significant. Calvin thought that evildoers corrupted good people faster than good people could save the evildoers ${ }^{54}$, which was a concern for accused heretics housed in prison with common criminals of both sexes. The temptation to despair was also common, and it could result in nervous or physical collapse, 55 making the person incapable of performing the ritual of the good death at the hour of death itself. If prison caused accused heretics to fall into temptation, and the opportunity arose to recant and be saved, it could be interpreted as God's deliverance. As Brad Gregory has noted, it might even be considered presumptuous for heretics to assume that God

\footnotetext{
53 John Scory, An Epistle Written by John Scory the late Bishop of Colchester Unto All the Faithful (London 1555), 11.

54 Bouwsma, 36.

55 Covington, 81.

Past Imperfect

16 (2010) | @ | ISSN 1711-053X | elSSN 1718-4487
} 
wanted their martyrdom after 'mercifully providing for...escape'. ${ }^{56}$

The Profitable Book for Man's Soul offered further advice for those who had fallen into temptation. The author advised the sinner to think of the strength he has a gift from God, to confess and to do penance. 'And then a great freedom and liberty, when a man is delivered of...the devil and made free to God by the sacrament of confession and penance. This liberty is a great strength against the fiend; also he that had no armour while he lay in sin, now he is armed with God's armour.'57 This suggested that confession and penance could restore strength. The penance of recantation could thus be both a punishment and a means of grace.

Another fear that tormented accused heretics preparing for the good death was whether or not their willingness to die for Christ was actually a desire to commit suicide in disguise. Suicide was considered a sin against God, king and nature by all confessions in early modern England. In a sermon in 1600, George Abbott told his congregants that 'none should spill the blood, or destroy the life of himself, for any cause whatsoever, because that is a deed most unchristian, most damnable, and most wicked.'58 Suicides did not even receive Christian burials; instead, the bodies were flung naked into a pit dug in a crossroads, pinned to the ground with a stake, and covered up. ${ }^{59}$ For accused heretics trying to learn the ars moriendi, it was therefore important to determine why they wanted to be

56 Gregory, 103.

57 Anonymous, The Profitable Book for Man's Soul (London, 1493), 18, 19.

58 George Abbott, An Exposition on the Prophet Jonah (London 1600), 132.

${ }_{59}$ Michael MacDonald and Terence Murphy, Sleepless Souls: Suicide in Early

Modern England (Oxford: Oxford University Press, 1990), 15.

Past Imperfect

16 (2010) | @ | ISSN 1711-053X | elSSN 1718-4487 
martyred. The line between desiring a death that glorified Christ and desiring death simply to end the struggle of life sometimes blurred, ${ }^{60}$ and if the real motivation was suicide, that eliminated the chance that their death would be considered martyrdom. One such potential martyr, Sir Thomas More, examined the theme of suicide in many of his works, and he recognized two patterns of suicides: sin - guilt - despair - suicide, and sin- shame - despair - suicide. In the first, suicidal people self-condemn, assume that their guilt makes them unworthy of life, and commit suicide. In the second, suicidal people sin, and fear of punishment causes them to fall into despair and kill themselves. ${ }^{61}$ In either case, suicide was the direct result of desperation and despair, which usually brought on a guilty conscience and made sinners believe that their sins were too heinous to be forgiven.

Such was the case of Francis Spira. His sin did not truly lie in his recantation, but in his despair and desperation. He could have saved both his life and his soul, had he chosen to do so, but he allowed despair to lead him into the sin of suicide. 62 So did a man by the name of Father Lea, according to a 1579 treatise by Edmond Bicknoll. Father Lea did not fulfill an oath he took and suffered greatly for it. Not sensing God's grace and the 'inward festering wound of a guilty conscience, void of hope, full of despair' led him to suicide. ${ }^{63}$ Recantation could be justified, but letting despair lead to suicide could not. It violated the obedience, faith, and willingness to submit to the mercy of God that was required by the ars moriendi.

60 Gregory, 103.

61 Green, 108.

62 Overell, 623.

63 Edmond Bicknoll, A Sword Against Swearing (London, 1579), 37.

Past Imperfect

16 (2010) | @ | ISSN 1711-053X | elSSN 1718-4487 
Despair was not the only way to violate the ars moriendi when it came to suicide. A careless lack of concern for preserving life could also lead to the sin of self-murder, and recantation could be justified in order to prevent it. In 1637, John Sym gathered up many of the deliberations regarding suicide that had been produced in the medieval and early modern eras and published them together as Life's preservative against self-killing. Or, An useful treatise concerning life and self-murder. In it, he divided self-murder into two forms: direct and indirect. In direct self-murder, the motivation is to end life. In indirect self-murder, the motivation is to attain some good, but the people who practice it do not consider the long-term effects carefully enough. To explain the difference, the case of Francis Spira becomes useful once again. Spira was guilty of direct self-murder via selfstarvation, a sin brought on by despair. If he had refused to recant, provoked the authority of the Inquisition in the name of defending his faith, and then allowed himself to be captured, he would have been guilty of indirect self-murder. Sym believed that people had a responsibility to preserve their own lives. He hastened to add that they should not ignore God or rely on their own strength to keep them safe, but reiterated that they should protect themselves as much as possible. 64

This conflicted with some reformist doctrine that preached absolute and passive obedience, and agreed with other traditions that advocated flight instead of capture. It also justified recantation, in some circumstances. In 1532, Bishop Latimer persuaded James Bainham to recant. Bainham had been imprisoned for dispraising St. Thomas Becket, and Latimer did

64 John Sym, Life's Preservative Against Self-Killing (London, 1637), 61-65.

Past Imperfect

16 (2010) | @ | ISSN 1711-053X | elSSN 1718-4487 
not consider that an issue worth dying for. As he said: 'Let not vainglory overcome you in a matter that men deserve not to die; for therein you shall neither please God, do good to yourself, nor your neighbor, and better it be for you to submit yourself to the ordinances of men, then so rashly to finish your life without good ground.' 65 Robert Glover also had to consider whether he should recant while in prison in 1555, because he feared that the sickness he was suffering would kill him before 'I should come to my answer, [making] my death to be unprofitable.'66 He might intend some good through his death, but the weakness of the flesh could take away the positive outcome, and taint those intentions with the stigma of self-murder.

The motivation for recantation played a role in its justification. Although Dr. Edward Crome recanted just as Spira had, his motivation for doing so was very different from theirs. The evidence of his life and the reputation he had at death shows that he recanted so that he could continue to preach and encourage others. He stood steadfast in his faith by refusing to stand steadfast in his words, and obeyed his sovereign by disobeying him. His death was a peaceful one, suggesting that he believed that he had achieved salvation and died the good death. Spira recanted from fear, ${ }^{67}$ gave his conscience more weight than the advice of the learned people who came to console him, and refused to accept God's mercy or trust in his grace. It is interesting to note that the story of Francis Spira was included in Foxe's Acts and Monuments as a warning, or, as Michael MacDonald explained it, as 'an inversion of the tales of

\footnotetext{
65 Wabuda 240.

66 Foxe, 1570, 187.

67 MacDonald, 32.
} 
steadfastness and saintly suffering that filled the volumes of his book.' 68 The life and death of Dr. Edward Crome was supposed to be fully described in the 1570 edition of Acts and Monuments, but it was reduced to the occasional mention because Foxe considered recantation a shameful punishment, not a heroic form of standing for the faith. 69

Foxe was one of the anti-Nicodemites who attempted to limit the ars moriendi to the martyrs, and he sometimes ignored or downplayed the fact that many of the martyrs had also recanted, at one point or another. ${ }^{70} \mathrm{He}$ also did not fully consider that the ars moriendi included the preparation for death, the acceptance of death, and the hour of death. Those who recanted could show that they had prepared for death by developing their faith, just as the martyrs had. They could show obedience. They could show willing acceptance of the mercy of God, patience during suffering, peaceful acceptance of God's will, and an attitude of loving forgiveness.

Dr. Edward Crome is an example of someone who achieved the good death although he did not receive nor answer the call to martyrdom. The story of his life shows that although recantation was used as a punishment by crown and church, it could also be used as a means of working out salvation in the quest to earn that free and sure passage to rewards in heaven. He struggled to live up to his beliefs in an atmosphere of religious conflict and persecution, which was a still a form of heroism even though it did not include enduring torture or violent death. Like

\footnotetext{
68 MacDonald, 39.

69 Wabuda, 239.

70 Wabuda 225.
} 
many others in early modern England who recanted, Dr. Crome may not have died for the faith, but he still died in the faith. 


\section{Bibliography}

Primary Sources

Abbot, George. An exposition vpon the prophet Ionah Contained in certaine sermons, preached in S. Maries Church in Oxford. By George Abbot Professor of Diuinitie, and Maister of Vniuersitie Colledge. London, 1600.

Anonymous. The Doctrynalle of dethe. London, 1498.

Anonymous. Here begynneth a lytell treatyse called ars moriendi. London, 1497.

Anonymous. The prouffytable boke for ma[n]nes soule, and right comfortable to the body, and specyally in aduersitee [and] trybulacyon, whiche boke is called The chastysing of goddes chyldern. London, 1493.

Askew, Anne, 1521-1546. The first examinacyon of Anne Askewe lately martyred in Smythfelde, by the Romysh popes vpholders, with the elucydacyon of Iohan Bale. London: 1546.

Bale, John. A soueraigne cordial for a Christian conscience Content thi selfe with pacience, with Christ to bear the cros of paine which can wil the rec[m]pence, a thousand fold with ioyes againe let nothig cause thi hart to quail lau[n]ch out thi bote, hoise vp the sail put from the shore. And thou sure thou shalt atain vnto the port that shall remayne, for euermore. London, 1554.

Bale, John. The vocacyon of Ioha[n] Bale to the bishiprick of Ossorie in Irela[n]de his persecucio[n]s in ye same, \& finall delyueraunce .... London, 1553.

\footnotetext{
Past Imperfect

16 (2010) | @ | ISSN 1711-053X | eISSN 1718-4487
} 
Bale, John. Yet a course at the Romyshe foxe A dysclosynge or openynge of the Manne of synne, co[n]tayned in the late declaratyon of the Popes olde faythe made by Edmonde Boner bysshopp of London. wherby wyllyam Tolwyn was than newlye professed at paules crosse openlye into Antichristes Romyshe relygyon agayne by a newe solempne othe of obedyence, notwythsta[n]dynge the othe made to hys prynce afore to the contrarye. An alphabetycall dyrectorye or table also in the ende thereof ... Compyled by Iohan Harryson. London, 1543.

Bicknoll, Edmond. A svvoord agaynst swearyng conteyning these principall poyntes. 1 That there is a lawful vse of an oth, contrary to the assertion of the Manichees \& Anabaptistes. London, 1579.

Bonde, William. A deuoute epystle of treaty for them that ben tymorouse and fearefull in conscience whiche treatyse yf yt be well red ouer [and] folowyd wyll brynge the reders out of all scrupulosite of conscience and seruyle feare, [and] brynge them to the holy feare and loue of almyghty God. Compyled by a brother of Syon (called wyllyam Bonde a Bacheler of Diuinitie) on whose soule Jesu haue mercy.... London, 1534.

Burnett, Gilbert. The History of the Reformation of the Church of England. London: 1679.

Calvin, John. A Sermon of the Famous and Godly Learned Man, Master Iohn Caluine. London, 1581.

Christopherson, John. An exhortation to all menne to take hede and beware of rebellion wherein are set forth the causes.. London, 1554.

\author{
Past Imperfect \\ 16 (2010) | ( ) | ISSN 1711-053X | elSSN 1718-4487
}


Foxe, John. Acts and Monuments [...] (1563 edition), [online]. (hriOnline, Sheffield). Available from: http://www.hrionline.shef.ac.uk/foxe/. [Accessed:

02.12.2009]

-------- Acts and Monuments [...] (1570 edition), [online].

(hriOnline, Sheffield). Available from:

http://www.hrionline.shef.ac.uk/foxe/. [Accessed:

02.12.2009]

Acts and Monuments [...] (1583 edition), [online].

(hriOnline, Sheffield). Available from:

http://www.hrionline.shef.ac.uk/foxe/. [Accessed:

04.12.2009]

Scory, John. An epistle wrytten by Iohn Scory the late bishope of

Chichester vnto all the faythfull that be in pryson in

Englande, or in any other troble for the defence of Goddes

truthe. London, 1555

Sym, John. Lifes preservative against self-killing. Or, An useful treatise concerning life and self-murder. London, 1637.

Printed Primary Sources

More, Sir Thomas. Utopia with The Dialogue of Comfort. London:

J.M. Dent and Sons, 1933.

Secondary Sources

Bouwsma, William J. John Calvin: A $16^{\text {th }}$ Century Portrait. New York: Oxford University Press, 1988.

Butler, Sara M., 'Degrees of Culpability: Suicide Verdicts, Mercy, and the Jury in Medieval England', Journal of Medieval 
and Early Modern Studies, 36, No. 2 (Spring 2006).

Byman, Seymour. 'Ritualistic Acts and Compulsive Behavior: The Pattern of Tudor Martyrdom', The American Historical Review, Vol 63, No 3 (June 1978).

Covington, Sarah. The Trail of Martyrdom: Persecution and Resistance in $16^{\text {th }}$ Century England. Notre Dame: Notre Dame Press, 2003.

Davis, John F., 'The Trials of Thomas Bylney and the English Reformation', The Historical Journal, 24, No 4 (December, 1981).

Duffy, Eamon. Fires of Faith: Catholic England Under Mary Tudor. New Haven: Yale University Press, 2009.

Gregory, Brad S. Salvation at Stake. Cambridge: Harvard University Press, 1999.

Green, Paul D. 'Suicide, Martyrdom, and Thomas More', Studies on the Renaissance, Vol 19 (1972).

Glickman, Gabriel, 'Early Modern England: Persecution, Martyrdom...and Toleration?', The Historical Journal, 51, No 1 (2008).

Loades, David. John Foxe and the English Reformation. Aldershot: Scolar Press, 1997.

Maclure, Millar. The Paul's Cross Sermons. Toronto: University of Toronto Press, 1958.

MacDonald, Michael. 'The Fearefull Estate of Francis Spira: Narrative, Identity, and Emotion in Early Modern England'. The Journal of British Studies, Vol. 31, No. 1 (Jan., 1992).

MacDonald, Michael and Terence Murphy. Sleepless Souls: Suicide in Early Modern England. Oxford: Oxford University Press, 1990. 
Marshall, Peter. Reformation England 1480-1642. London: Hodder Education, 2003.

O'Conner, Sister Mary Catherine The Art of Dying Well: The Development of Ars Morendi. New York: Columbia University Press, 1942.

Overell, M.A. 'The Exploitation of Francesco Spiera'. The Sixteenth Century Journal, Vol. 26, No. 3 (Autumn, 1995).

Sharpe, J.A.. 'Last Dying Speeches: Religion, Ideology, and Public Execution in Seventeenth Century England', Past and Present, 107 (May 1985).

Smith, Lacey Baldwin. "English Treason Trials and Confessions in the Sixteenth Century", Journal of the History of Ideas, Vol 15, No 4 (October 1954).

---------. "Henry VIII and the Protestant Triumph", The American Historical Review, Vol 71, No 4 (July 1966)

Tjernagel, Neelak Serawlook. Henry VIII and the Lutherans. Saint Louis: Concordia, 1965.

Wabuda, Susan. 'Equivocation and recantation during the English reformation: The 'subtle shadows' of Dr Edward Crome.' The Journal of Ecclesiastical History, 44, no. 2 (April 1, 1993): 224. http://www.proquest.com/ (accessed November 30, 2009).

-------,'Crome, Edward (d. 1562).' In Oxford Dictionary of National Biography, edited by H. C. G. Matthew and Brian Harrison. Oxford: OUP, 2004. Online ed., edited by Lawrence Goldman, January 2008. http://www.oxforddnb.com/view/article/6749 (accessed December 11, 2009).

Walsham, Alexandra. 'Bell, Thomas (b. c.1551, d. in or after 
1610).' In Oxford Dictionary of National Biography, edited

by H. C. G. Matthew and Brian Harrison. Oxford: OUP,

2004. Online ed., edited by Lawrence Goldman, January

2008. http://www.oxforddnb.com/view/article/2026

(accessed December 4, 2009).

Wight, Jonathan. 'The World's Worst Worm: Conscience and

Conformity During the English Reformation', The 65

Sixteenth Century Journal, Vol 30, No 1 (Spring 1999): 